\title{
The Effect of Tax Risk on Tax Avoidance
}

\author{
Yenni Mangoting 1 , Oviliani Yenty Yuliana², Jesslyn Effendy ${ }^{3 *}$, Lovena \\ Hariono ${ }^{4}$ Viennie Melinda Lians ${ }^{5}$ \\ 1,2,3,4,5Department of Accounting, Petra Christian University, Indonesia \\ ${ }^{*}$ Corresponding Author: jesslyneffendy@gmail.com
}

\begin{abstract}
This research intends to investigate whether tax risk is associated with tax avoidance, which is proxied by Cash Effective Tax Rate (CETR). Tax risk is measured by six tax risk components: transactional risk, compliance risk, operational risk, financial accounting risk, managerial risk, and reputational risk. The samples in this research are manufacturing companies listed on the Indonesian Stock Exchange (IDX). With a purposive sampling method, there are 168 firm years which we analyzed with OLS regression. The result in this study showed that tax risk is positively associated with CETR. It implied that choices of tax strategies and activities are involved in high tax risk, but firms still choose to comply with tax regulations, which can be seen in high CETR values. This research found that firms need tax risk management to ensure that tax strategies do not impact the firms' future losses from additional tax payments and fines. Other than that, this research gives a new option for future researchers to measure tax risk using scoring methods and indicators that are engaged in each of the tax risk components.
\end{abstract}

Keywords: CETR; Taxation; Tax Avoidance; Tax Risk; Uncertainty

\section{INTRODUCTION}

Generally, prior studies about tax avoidance have been more focused on how the choice of a company's strategies could provide tax benefits through lower Effective Tax Rate (ETR) value. For example, recent investigations between tax avoidance and cost of debt (Kovermann, 2018; Hutchens \& Rego, 2013), CSR (Zeng, 2019), tunneling strategy for a tax benefit (Tang, 2016), and transfer pricing strategies (Amidu et al., 2019). However, these activities could lead to failure because of uncertainties in the business environment where the company belongs.

Tax risk occurs when there is variability in taxation law, inconsistencies in the implementation of taxation, poor authorities' enforcement, possible audits in the future, and frequent changes in tax rates and provisions that formed uncertainties or tax risk in the future (Sreesing, 2018; Chen, 2020a, 2020b). Drake et al. (2019) defined tax risk as all 
tax-related uncertainties inherent in a firm's transactions, whether related to the operational, financial reporting decisions, and reputation. According to Lin et al. (2019), tax risk differs from tax aggressiveness which only has short-term objectives to reduce tax payments. High tax risks can be imposed because of aggressive tax planning (Kovermann, 2018). According to Kovermann (2018), there is a negative association between the cost of debt and tax avoidance and a positive association between tax risk and tax avoidance. Creditors give a positive assessment of tax avoidance by lowering the cost of debt. However, when the tax avoidance level is too high, creditors could assess the company as risky and give the higher cost of debt.

One of the inherent risks in firms' transactions is tax risk. Tax risk has negative impacts on the firm's future sustainability because high uncertainties could lead to unplanned financial losses (Artemenko et al., 2017). For example, investment decisions are essential for managers because these activities are risky and may impose high economic costs, such as unwanted tax and fines in the future (Lin et al., 2019). Another example is transfer pricing transactions which can be complex and cause a significant increase in tax risk because those also increase overall future cash flow (Goh et al., 2016).

Besides transactional risk, tax risk can be in the form of reputational risk, which is the extent to which tax planning activities have impacts on a company's brand image. Companies with a low debt-to-equity ratio tend to consider reputational risk more carefully and sometimes minimize risky investment decisions than companies with a high debt-to-equity ratio (Sreesing, 2018). Low debt-to-equity ratio companies will increase debt level only if they need to give creditors appropriate protection through tax avoidance. Therefore, benefits from a good reputation are being compared with benefits of tax avoidance. On the one hand, give guarantees related to the availability of future cash flows to pay leverages, while on the other hand, also increase tax risk in the future. This study is in line with (Masri et al., 2019), which explained that tax risk is positively associated with tax avoidance level. Therefore firms need tax risk management to reduce it. However, different analyses are shown in Abduh et al. (2014), which explained that high tax risk is negatively associated with tax avoidance. This means that risky transactions which firms took are causing ineffectiveness in tax avoidance activities.

The manufacturing sector is chosen for this research because it is a dominant sector that forms Indonesia's GDP, which means the manufacturing sector is the biggest contributor to tax revenue in Indonesia (Carolina \& Handayani, 2019; Muryani \& Chiputyani, 2019). The manufacturing sector also has a large sample size, which dominantly consists of large-sized companies. From data gathered by Kementerian Perindustrian Republik Indonesia, in 2017 tax revenue realization rate from the manufacturing sector grew $16,63 \%$ compared to the previous year. However, Indonesia still couldn't reach its optimum tax revenue rate as the result of many companies doing tax avoidance activities which this research is going to investigate.

Based on the background explained before, it is essential to investigate how tax risk affects a firm's tax avoidance activities. In this research, we would like to measure tax risk by its relevant business activities. Therefore, tax risk is proxied by transactional risk, operational risk, compliance risk, financial accounting risk, managerial risk, and reputational risk. Our research examines the benefits companies get from taking additional tax risk on their tax planning decisions, which can be seen in the CETR values. A low CETR value indicates a low corporate tax payment rate and the success of 
corporate tax avoidance in its tax planning. As a result of engaging in risky tax planning, managers need to assess and manage higher tax risk. Therefore, this research will help the managers and tax practitioners to assess firms' tax risk using our tax risk scoring, which is based on the firms' activities made by the managers.

\section{HYPOTHESIS DEVELOPMENT}

Tax avoidance has been explained as "tax reduction activities ranging from taxprofitable investments to aggressive strategies" (Dyreng et al., 2019) and "activities that generate cash tax savings and provide financial reporting benefits" (Hutchens et al., 2020). In this study, we would like to investigate the relationship between tax avoidance and tax risk, adapted from the research model of Neuman et al. (2013) that is developing and validating the tax risk score and then investigating the association between the tax risk score and tax avoidance. Measuring tax risk based on scoring is rarely used, especially for research in Indonesia. Tax risk is different from business risks because tax law and revenue authority oversight influences future tax outcomes uncertainty (Neuman et al., 2020). The tax risk measured in this research is classified into six tax risk components.

Transactional risk is risk and exposure associated with a firm's specific transactions because of uncertainties. The more unusual and uncommon the transactions are, the bigger the tax risk possibilities related to those transactions (Neuman et al., 2013). Operational risk is the risk of loss resulting from inadequate or failed internal processes, people, and systems or external events, including the uncertainty in applying tax laws to routine operations (Cozmei \& Şerban, 2014). With the increase in trade globalization, there will be an increase in operational risk because of the country's taxable presence in which they are operating.

Compliance risk is a risk associated with meeting an organization's tax compliance obligations. Complexity is also becoming one of many factors that increases a firm's compliance risk. Complexity increases ignorance behavior in managers (Emblemsvåg, 2020), affecting the information quality, especially related to the tax payments. Financial accounting risk is risk in financial statement reporting, such as a material error caused in a not faithfully represented financial statement. We measured it by the delay in submitting financial reports. Prior research consistently found a positive association between late accounting reports and low-quality earnings (Cao et al., 2016).

Reputational risk occurred in return for management's effort to reduce tax payments using tax avoidance activities (Lavermicocca \& Buchan, 2015). Therefore, reputational risk is valued as necessary by the executives in decision-making processes related to tax avoidance. Ineffective management in allocating a firm's resources, such as skills, time, and expenses, can lead to unintended managerial risk (Cozmei \& Şerban, 2014). Therefore, firms with high managerial risk have a low quality of resources and lack management skills.

Agency theory in tax avoidance can be seen as an opportunist act conducted by taxpayers to gain maximum tax benefits. In the practice of agency theory, managers will look for ways to minimize tax expenses through tax planning which mostly are not consistent with government regulation related to taxation and result in more considerable earnings after tax (Putra et al., 2018). These actions are contrary to tax authorities' beliefs 
that tax is a significant income for the country. Engaging in tax planning could increase managers' rewards to deal with more tax risk (Neuman et al., 2013). In line with Neuman et al. (2013), there is a negative association between tax risk and CETR, which means that firms are inclined more in risky tax planning because they can lower tax expenses in the form of lower CETR.

$\mathrm{H}_{1}$ : Tax risk is negatively associated with CETR

\section{METHOD, DATA, AND ANALYSIS}

\section{Sample Selection}

We use the purposive sampling method for the sample selection shown in Table 1.

Table 1. Purposive Sampling

(-) Incomplete Annual Report Data

(-) CETR is less than 0 or more than 1

Total sample (number of firms)

\section{Research Model}

This type of research is a quantitative research method using Ordinary Least Square (OLS) regression analysis. To test the hypothesis, the research model is as follows equation 1.

$$
\text { CETRit }=\beta 0+\beta 1 \text { TRISKit }+\beta 2 \text { LVGit }+\beta 3 \text { PMit }+\beta 4 \text { INVit }+\beta 5 \text { SGAit }+\beta 6 \text { BMit }+\varepsilon
$$

\section{Variables}

Independent Variable:

CETR (Cash Effective Tax Rate) = cash tax paid divided by pretax income

Dependent Variable:

TRISK

Control Variables:

LVG (Leverage)

$P M$ (Profit Margin)

INV (Inventory Intensity)
$=$ total score of each tax risk component (as shown in Table 2)

$=$ long-term debt divided by total assets

$=$ pretax income divided by total sales

$=$ inventories divided by prior total assets 
SGA (Selling, General, and, Administration Expense) BM (Book-to-Market ratio)
$=$ SGA expenses divided by prior total assets

$=$ the natural $\log$ of the ratio of common book equity divided by the market value of equity

Cash Effective Tax Rates (CETR) are often used to proxy for tax avoidance (Drake et al., 2019; Hutchens et al., 2020). To measure tax risk, we identify whether a firm engages in transactions or has characteristics associated with tax risk categories and then assign a score for each of the risks. Higher values of the tax risk score indicate higher levels of tax risk. We follow Neuman et al. (2013) study examining the transactions associated with each of the six categories of tax risk, explained below.

The variation payments of merger/acquisition may increase transactional risk and become one of the manager's many important choices (Sankar \& Leepsa, 2018). Apart from payment procedures, mergers/acquisitions signal weak internal controls within firms (Gleason et al., 2017). Discontinued operations are defined as a disposal of significant business lines or segments and are often used by earning management as a tool for classification shifting (Skousen et al., 2019). These two are unusual transactions in which accounting processes are less equipped to handle such transactions and could lead to financial reporting misstatement. Lastly, financing transactions create tax risk because of their infrequent occurrence and extensive documentation requirements (Neuman et al., 2013). Capital structure decisions could lead to uncertainties because of different taxation treatments between debt and equity capital structures and induce a mismatch (KPMG, 2017).

Companies with foreign operations, or multinational companies, have more significant tax avoidance opportunities since they can exploit lower foreign tax rates by shifting income to other foreign subsidiaries (Contractor, 2016). They also have more complex decision-making related to different routine environments, cultures, and policies (Asmussen et al., 2016; Birkinshaw et al., 2020), resulting in increased firms' operational risk. In line with multinational companies, tax haven countries have lower and even zero tax rates lower tax expenses. Operating a subsidiary in a tax haven country leads to an operational tax risk due to increased government scrutiny of possible reallocation of income from tax haven operations (Álvarez-Martínez et al., 2021). Another proxy used is operational volatility, directly related to the uncertainty in measuring a firm's annual taxable income and tax payment, which involves higher tax risks (Artemenko et al., 2017).

Large firms with many geographic and business segments that are not well concentrated are more complex because of different taxation laws, currency, etc. This situation can result in a more significant risk that firms have to bear. Using the theory of cost and concluded that a company's larger size and profit could lead to a higher possibility of tax avoidance activities because of the higher expenses paid in tax (Kim \& Im (2017). Sugeng et al. (2020) also said that larger firms incurred higher political advantages because they can do tax planning to reduce taxes that must be paid using existing gaps. The reason is that larger firms have more resources to be invested in their internal tax department. The next component is tax deferral, which tax departments usually use to reduce ETR by delaying the recognition of taxable income and accelerating tax deductions or tax savings (Mulatsih et al., 2019). Deferred tax liability causes a negative fiscal correction. It is also difficult to keep two sets of books, resulting in not 
complying with tax regulations (Neuman et al., 2020). Therefore, deferred taxes could lead to additional regulatory scrutiny.

Firms that are late in their annual and quarterly report submission can raise their financial accounting risks. This late submission indicates a low financial report's quality resulting in shareholders' negative perception, auditors' skepticism, and bad publicity (Cao et al., 2016). A study by Chiu et al. (2018) found that annual and quarterly reports late submission is associated with material weakness in firms' internal control. Thus, auditors might assess higher risks of material misstatement.

Ineffective management in managing firms' activities is a managerial risk that can be seen from an inability to reserve competent employees or inadequate competencies in current employees, which lead to the dismissal (Cozmei \& Şerban, 2014). High employment volatility indicated that most employees are not familiar with the process and business practices, increasing managerial risks (Neuman et al., 2020). Firms could also hire outside tax experts if there are no skills available for tax planning, especially if there are unusual tax transactions and employees have inadequate knowledge to administer them. Hiring external tax experts could reflect high tax avoidance in hirer companies. Goh et al. (2015).

More media exposure on a firm causes more considerable pressure and attention from the public, resulting in risks for the firm (Kanagaretnam et al., 2018). An apparent firm to the public can get negative press when disclosing tax issues (Neuman et al., 2020). Reputational risk occurred in return for management's effort to reduce tax payments using tax avoidance activities, which caused uncertainties about litigation and damaged brand name in the future (Wang et al., 2020). Lastly, institutional shareholders are government ownership, insurance companies, foreign investors, and banks (Oktaviyani \& Munandar, 2017). According to F. Wang et al. (2020), institutional shareholders and tax avoidance are positively associated. These institutional shareholders made a more significant risk for firms because they have big influences and credibility on the marketplace and resulted in more reputational risk.

This research will measure the tax risk variable with a scoring method for each tax risk component based on the explanation above. The description for each tax risk components indicators is shown in Table 2. The number assigned for each tax risk component will be varied based on the activities engaged by firms.

Table 2. Tax Risk Indicators

\begin{tabular}{|c|c|c|c|}
\hline \multirow{2}{*}{$\begin{array}{l}\text { TAX RISK } \\
\text { INDICATORS }\end{array}$} & \multirow{2}{*}{ DEFINITION } & \multicolumn{2}{|c|}{ SCORE } \\
\hline & & MIN & MAX \\
\hline TR_ACQ & TR_ACQ is 1 for firms that have M\&A activity in the period & 0 & 1 \\
\hline TR_DOP & TR_DOP is 1 for firms that have discontinued operations in the period & 0 & 1 \\
\hline TR_FTR & $\begin{array}{l}\text { TR_FRT is } 1 \text { for firms either issuing bonds or shares, two if issuing } \\
\text { both }\end{array}$ & 0 & 2 \\
\hline OR_FOP & OR_FOP is the tertile rank of the firm's foreign income & 0 & 3 \\
\hline
\end{tabular}




\begin{tabular}{|c|c|c|c|}
\hline \multirow{2}{*}{$\begin{array}{l}\text { TAX RISK } \\
\text { INDICATORS }\end{array}$} & \multirow{2}{*}{ DEFINITION } & \multicolumn{2}{|c|}{ SCORE } \\
\hline & & MIN & MAX \\
\hline OR_SV3 & $\begin{array}{l}\text { OR_SV3 is the quartile rank of sales volatility, measured from the } \\
\text { standard deviation of annual sales from } t-2 \text { to } t\end{array}$ & 1 & 4 \\
\hline OR_TXH & $\begin{array}{l}\text { OR_TXH is the tertile rank of the number of subsidiaries that are in } \\
\text { tax haven countries (Gravelle, 2009) }\end{array}$ & 0 & 3 \\
\hline CR_BSG & CR_BSG is the tertile rank of the number of business segments & 1 & 3 \\
\hline CR_GSG & CR_GSG is the tertile rank of the number of geographic segments & 1 & 3 \\
\hline CR_SIZ & CR_SIZ is the quartile rank of the natural log of assets & 1 & 4 \\
\hline CR_DTL & $\begin{array}{l}\text { CR_DTL is the tertile rank of deferred tax liabilities divided by lagged } \\
\text { assets }\end{array}$ & 0 & 3 \\
\hline CR_FEE & MR_FEE is 1 for firm's with tax department & 0 & 1 \\
\hline FR_IEA & FR_IEA is the quartile rank of late reporting of quarterly earnings & 0 & 4 \\
\hline FR_AEA & $\begin{array}{l}\text { FR_AEA is the quartile rank of late reporting of annual earnings (Q4), } \\
0 \text { if otherwise. }\end{array}$ & 0 & 4 \\
\hline FR_TKL & FR_TKL is the quartile rank of late reporting of annual reports & 0 & 4 \\
\hline MR_EMP & $\begin{array}{l}\text { MR_EMP is the quartile rank of the standard deviation of total } \\
\text { employees from years } t-2 \text { to } t \text {. }\end{array}$ & 1 & 4 \\
\hline MR_EXP & MR_EXP is one of the firms that hire an outside tax expert & 0 & 1 \\
\hline RR_ADM & RR_ADM is 1 for firms that received awards in the period & 0 & 1 \\
\hline RR_SET & RR_SET is 1 for firms that have litigation or legal cases in the period & 0 & 1 \\
\hline RR_IST & RR_IST tertile rank of the number of institutional shareholders & 0 & 3 \\
\hline & TOTAL & 5 & 50 \\
\hline
\end{tabular}

Notes: $\mathrm{TR}=$ Transactional Risk, $\mathrm{OR}=$ Operational Risk, $\mathrm{CR}=$ Compliance Risk, FR $=$ Financial Accounting Risk, MR = Managerial Risk, RR = Reputational Risk. Source: Indicators for TRISK components are adapted from prior study (Neuman et al., 2013, 2014, 2020).

We include LVGit as our control variable. The larger the leverage ratio is, the larger the interest expense will be, which can be deducted from taxable income and become the tax shield benefit for firms (Sari, 2017). Prior studies have found that higher profit margins drive the firm's future tax avoidance higher, which indicates that profit margin has a negative association with CETR (Khatami et al., 2021). Firms with higher inventory intensity tend not to be aggressive (Nurfauzi \& Firmansyah, 2018). Therefore, it can be inferred that INVit is positively associated with CETR. SGA expenses can be tools for managers' discretion for income shifting to decrease income tax payments (Badertscher et al., 2018). It can be said that SGAit is negatively associated with CETR. Lastly, BMit is 
used to control the extent to which value and growth opportunities for companies (Moghadam \& Rahimi, 2016), and therefore is used as a risk control measure.

\section{RESULTS}

The selected samples are 43 companies within four years from 2016 to 2019, or 172 firm-years observations. The summary of the results of descriptive statistics in this study is presented in Table 3. When we conducted a regression analysis, we found an outlier from one of the firm samples, which affected our results' validity. As a consequence, we removed this outlier, and therefore the remaining observations are 168 firm years.

Table 3. Descriptive Statistics

\begin{tabular}{cccccc}
\hline Variables & $\mathbf{N}$ & Mean & St. Dev. & Minimum & Maximum \\
\hline TRISKit & 168 & 22.738 & 7.034 & 8.000 & 41.000 \\
CETRit & & 0.253 & 0.106 & 0.002 & 0.711 \\
LVGit & 0.083 & 0.121 & 0.000 & 0.490 \\
PMit & 0.117 & 0.083 & 0.010 & 0.530 \\
INVit & 0.214 & 0.121 & 0.010 & 0.620 \\
SGAit & 0.197 & 0.167 & 0.248 & 0.850 \\
BMit & -0.671 & 1.061 & -4.412 & 1.497
\end{tabular}

Source: Author's Processed Results Based on SPSS Output

Table 4 shows that Kolmogorov-Smirnov Asymp. Sig. (2-tailed) value in our data is 0.200 , which is greater than $5 \%$, so it can be said that our data is normally distributed. The multicollinearity test can be seen from the VIF value, which is less than 10, which means that independent variables are free from multicollinearity. The autocorrelation test is seen from the Durbin-Watson value. DW table shows $\mathrm{dL}=1.2022$ and $\mathrm{dU}=1.8451$, which means that our DW value is in the middle of $\mathrm{dU}$ and 4-dU, and there is no positive autocorrelation in the model. Lastly, we conduct a heteroscedasticity test that can be seen from sig. Values are more significant than $5 \%$, which means there is no heteroscedasticity problem. Therefore, all of the classic assumptions are satisfied.

Table 4. Classic Assumption Test

\begin{tabular}{ccccccc}
\hline \multirow{2}{*}{ MODEL } & \multicolumn{2}{c}{ Normality } & \multicolumn{2}{c}{ Multicollinearity } & Autocorrelation & \multicolumn{2}{c}{ Heteroscedasticity } \\
\cline { 2 - 7 } & Kolmogorov-Smirnov & Tolerance & VIF & $\begin{array}{l}\text { Durbin- } \\
\text { Watson }\end{array}$ & $\mathbf{t}$ & Sig. \\
\hline TRISKit & Asymp. Sig. (2-tailed) & 0.631 & 1.584 & & 1.799 & 0.074 \\
LVGit & 0.200 & 0.686 & 1.457 & & -1.231 & 0.220 \\
\hline
\end{tabular}




\begin{tabular}{|c|c|c|c|c|c|c|}
\hline \multirow{2}{*}{ MODEL } & \multirow{2}{*}{$\begin{array}{c}\text { Normality } \\
\text { Kolmogorov-Smirnov }\end{array}$} & \multicolumn{2}{|c|}{ Multicollinearity } & \multirow{2}{*}{$\begin{array}{l}\text { Autocorrelation } \\
\text { Durbin- } \\
\text { Watson }\end{array}$} & \multicolumn{2}{|c|}{ Heteroscedasticity } \\
\hline & & Tolerance & VIF & & $\mathbf{t}$ & Sig. \\
\hline PMit & & 0.452 & 2.213 & & -1.482 & 0.140 \\
\hline INVit & & 1.159 & 1.159 & & 1.606 & 0.110 \\
\hline SGAit & $\begin{array}{c}\text { Asymp. Sig. (2-tailed) } \\
0.200\end{array}$ & 0.744 & 1.344 & 1.920 & -0.792 & 0.430 \\
\hline BMit & & 0.373 & 2.684 & & 0.357 & 0.721 \\
\hline
\end{tabular}

Source: Author's Processed Results Based on SPSS Output

\section{DISCUSSION}

Table 5 shows that total tax risk is positively associated with CETR, which can be seen that the coefficient is 0.003 and the sig value is 0.021 or less than $5 \%$, which is significant. The R Square value is $12.7 \%$, which explains that our independent and control variables can only explain $12.7 \%$ of the relationship with the dependent variable. In contrast, the remainder is explained by other variables which are not included in this model. Some of our control variables (LVGit and INVit) are significantly associated with our dependent variable-CETR, while other variables (PMit, SGAit, and BMit) are not significantly associated with CETR.

Based on the analysis result, H1 is not accepted. This finding is in line with Abduh et al. (2014) where they found a positive association between tax risk and CETR. According to Guenther et al. (2017), there are several ways to increase tax avoidance without an associated increase in tax risk. Only after firms exhaust these no risky tax avoidance opportunities would we expect a risk-return trade-off. A prior study also found that higher tax risk is associated with higher CETR if managers cannot manage the risk effectively (Neuman et al., 2013). Another point of view in this result is explaining that revenue authorities have effectively implemented law enforcement. Firms used highrisk tax activities while maintaining compliance with the law requirements. This result is in line with Wang (2015), which investigated higher taxation law enforcement resulting in higher risk, which firms tried to anticipate the potential loss from future additional tax payment and fines.

In this study, the samples we observed are big manufacturing companies with more significant capacities to manage resources efficiently. According to Sreesing (2018), largesized companies that run their business in high tax rates countries take more risky investment decisions. These considerations are based on the effort to utilize tax shields inherent in each of the firms' activities. High-risk activities, such as mergers and acquisitions, transfer pricing, discontinued operations, and many more, give tax benefits to firms, although at the same time also put firms in high-tax risk positions. It means that high tax avoidance is positively valued by shareholders but may be seen as the firm's negative effects for increasing the tax risk. 
Table 5. Hypothesis Test

$$
\begin{aligned}
& \text { CETRit }=0.184+0.003 \text { TRISKit }-0.272 \text { LVGit }-0.059 \text { PMit }+0.137 \text { INVit } \\
& +0.021 \text { SGAit }+0.013 \text { BMit }+\varepsilon \\
& \text { Dependent Variable: CETRit }
\end{aligned}
$$

\begin{tabular}{lccc}
\hline \multicolumn{1}{c}{ Variable } & Expectation Sign & Coefficient & Probability \\
\hline & - & Independent Variables & \\
\hline TRISKit & - & 0.003 & $0.021^{* *}$ \\
LVGit & - & -0.272 & $<0.001^{* * *}$ \\
PMit & + & -0.059 & 0.673 \\
INVit & - & 0.137 & $0.049^{* *}$ \\
SGAit & $?$ & 0.021 & 0.698 \\
BMit & 0.013 & & 0.281 \\
\hline \multirow{5}{c}{ Adjusted R Square } & & 0.127 \\
\hline & Sig. F & 0.095 & \\
\hline
\end{tabular}

***) Significance level at 1\%;

**) Significant level at $5 \%$.

Source: Author's Processed Results on SPSS Output

In Indonesia, external factors such as variability in taxation laws, law enforcement, inconsistencies in the tax, tax audits, high tax rates, and frequent changes in tax requirements are forming the uncertainty in the firm's taxation (Firmansyah \& Muliana, 2018). On the other hand, firms in this research's sample respond to uncertainty by complying with tax regulations and requirements. In summary, although firms could gain benefits from tax shields through tax avoidance, tax risk in Indonesia, as a developing country, is dominated by a firm's external factors and not by internal factors, which we used as proxies in tax risks.

Satyadini et al. (2019) also found that tax aggressiveness level is based on the extent of marginal benefits and marginal costs. If the marginal cost is greater than the benefits, firms will be less involved in aggressive tax avoidance. Taxation as a significant financial source for Indonesia also increases scrutiny of the company's tax strategies. Recent studies (Hamilton \& Stekelberg, 2016; Guenther et al., 2017; Lin et al., 2019) also indicated that paying lower taxes does not necessarily increase tax risk. 


\section{CONCLUSION, LIMITATIONS, AND SUGGESTIONS}

The purpose of this study was to investigate the effect of tax risk on tax avoidance. We use different measurements for tax risk variables by using six components of tax risks, such as transactional risk, operational risk, compliance risk, financial accounting risk, managerial risk, and reputational risk as proxies for tax risk and CETR a proxy for tax avoidance. Tax risk affects tax avoidance because it is about the uncertainty of future tax outcomes. Tax risk can be handled by conducting tax planning in the firm in which higher tax risk can produce lower CETR. We found a positive association between tax risk and CETR. This finding could possibly happen because of bad tax planning that is conducted within the firms or there are increases in tax control by the Directorate General of Tax to escalate Indonesia's source of income. The results also reflected the effectiveness of tax law enforcements during the period time of the samples, for example the success of tax amnesty policies that increase the compliance in taxpayers' behavior.

This study's limitations are that many firms have incomplete data and have operating losses, so we cannot analyze them in our study. We also had difficulties in finding and collecting data for tax risk indicators, therefore we suggest extending the period of time for the samples. Other suggestions for future researchers are to use other dependent variables as proxies for tax avoidance, like long years-period of CETR or ETR, and different industrial sectors as the sample. Using tax planning as a mediating variable in future studies can also be the other suggestions to enrich the research.

\section{REFERENCES}

Abduh, A., Andreas, \& Ratnawati, V. (2014). Pengaruh Kebutuhan Koordinasi, Ketidakpastian, dan Risiko Pajak terhadap Tax Avoidance. Jurnal Akuntansi Media Riset Akuntansi $\mathcal{E}$ Keuangan, 3(1), 16-28. https://ejournal.unri.ac.id/index.php/JA/article/view/2532

Álvarez-Martínez, M. T., Barrios, S., d'Andria, D., Gesualdo, M., Nicodeme, G., \& Pycroft, J. (2021). How large is the corporate tax base erosion and profit shifting? A general equilibrium approach. Economic Systems Research, 1-32. https:// doi.org/10.1080/09535314.2020.1865882

Amidu, M., Coffie, W., \& Acquah, P. (2019). Transfer pricing, earnings management and tax avoidance of firms in Ghana. Journal of Financial Crime, 26(1), 235-259. https://doi.org/10.1108/JFC-10-2017-0091

Artemenko, D. A., L.A.Aguzarova, F.S.Aguzarova, \& Porollo, E. V. (2017). Causes of Tax Risks and Ways to Reduce Them. EUROPEAN RESEARCH STUDIES JOURNAL, XX(Issue 3B), 453-459. https:/ / doi.org/10.35808/ersj/800

Asmussen, C. G., Larsen, M. M., \& Pedersen, T. (2016). Organizational Adaptation in Offshoring: The Relative Performance of Home- and Host-Based Learning Strategies. Organization Science, 27(4), 911-928. https:// doi.org/10.1287/orsc.2016.1060

Ayers, B. C., Laplante, S. K., \& Schwab, C. (2011). Does Tax Deferral Enhance Firm Value? SSRN Electronic Journal. https:/ / doi.org/10.2139/ssrn.1976606 
Badertscher, B. A., Katz, S. P., Rego, S. O., \& Wilson, R. J. (2018). Conforming Tax Avoidance and Capital Market Pressure (SSRN Scholarly Paper ID 2619317). Social Science Research Network. https:// doi.org/10.2139/ssrn.2619317

Birkinshaw, J., Larsen, M. M., Zhou, Y. M., \& Benito, G. R. G. (2020). COMPLEXITY AND MULTINATIONALS. Global Strategi Journal.

Cao, J., Chen, F., \& Higgs, J. L. (2016). Late for a very important date: Financial reporting and audit implications of late 10-K filings. Review of Accounting Studies, 21(2), 633671. https://doi.org/10.1007/s11142-016-9351-5

Carolina, V., \& Handayani, R. (2019). Tax Avoidance \& Corporate Risk: An Empirical Study in Manufacturing Company. Jurnal Ilmiah Akuntansi, 4(2), 10. https:// doi.org/10.23887/jia.v4i2.21886

Chen, W. (2020a). Tax risks control and sustainable development: evidence from China. Meditari Accountancy Research, https://doi.org/https://doi.org/10.1108/MEDAR05-2020-0884

Chen, W. (2020b). Too far east is west: tax risk, tax reform and investment timing. International Journal of Managerial Finance, https://doi.org/DOI10.1108/IJMF-032020-0132

Chiu, T., Huang, F., Liu, Y., \& Vasarhelyi, M. A. (2018). The impact of non-timely 10-Q filings and audit firm size on audit fees. Managerial Auditing Journal, 33(5), 503-516. https:/ / doi.org/10.1108/MAJ-10-2017-1673

Contractor, F. J. (2016). Tax Avoidance by Multinational Companies: Methods, Policies, and Ethics. AIB Insights. https:// doi.org/10.46697/001c.16887

Cozmei, C., \& Şerban, E. C. (2014). Risk Management Triggers: From the Tax Risk Pitfalls to Organizational Risk. Procedia Economics and Finance, 15, 1594-1602. https:// doi.org/10.1016/S2212-5671(14)00630-3

Drake, K. D., Lusch, S. J., \& Stekelberg, J. (2019). Does Tax Risk Affect Investor Valuation of Tax Avoidance? Journal of Accounting, Auditing \& Finance, 34(1),151-176. https:// doi.org/10.1177/0148558X17692674

Dyreng, S. D., Hanlon, M., \& Maydew, E. L. (2019). When Does Tax Avoidance Result in Tax Uncertainty? The Accounting Review, 94(2), 179-203. https:// doi.org/10.2308/accr-52198

Emblemsvåg, J. (2020). Risk and complexity on complex risk management. The Journal of Risk Finance, 21(1), 37-54. https:// doi.org/10.1108/JRF-09-2019-0165

Firmansyah, A., \& Muliana, R. (2018). The Effect of Tax Avoidance and Tax Risk on Corporate Risk. Jurnal Keuangan Dan Perbankan, 22(4), 643-656. https:// doi.org/10.26905/jkdp.v22i4.2237

Gleason, C. A., Pincus, M., \& Rego, S. O. (2017). Material Weaknesses in Tax-Related Internal Controls and Last Chance Earnings Management. Journal of the American Taxation Association, 39(1), 25-44. https://doi.org/10.2308/atax-51511 
Goh, B. W., Lee, J., Lim, C. Y., \& Shevlin, T. (2016). The Effect of Corporate Tax Avoidance on the Cost of Equity. Accounting View, 91(6). https:/ / doi.org/10.2308/accr-51432

Goh, B. W., Lee, J., \& Ng, J. (2015). The Inclusion of General Counsel in Top Management and Tax Avoidance. SSRN Electronic Journal. https:// doi.org/10.2139/ssrn.2538292

Gravelle, J. G. (2009). Tax Havens: International Tax Avoidance and Evasion. National Tax Journal, 62(4), 727-753. https:/ / doi.org/10.17310/ntj.2009.4.07

Guenther, D. A., Matsunaga, S. R., \& Williams, B. M. (2017). Is Tax Avoidance Related to Firm Risk? The Accounting Review, 92(1), 115-136. https://doi.org/10.2308/accr51408

Hamilton, R., \& Stekelberg, J. (2016). The Effect of High-Quality Information Technology on Corporate Tax Avoidance and Tax Risk. Journal of Information Systems, 31(2), 83106. https://doi.org/10.2308/isys-51482

Hutchens, M., \& Rego, S. (2013). Tax Risk and the Cost of Equity Capital. Working Paper.

Hutchens, M., Rego, S. O., \& Williams, B. (2020). Tax Avoidance, Uncertainty, and Firm Risk (SSRN Scholarly Paper ID 3348559). Social Science Research Network. https:// doi.org/10.2139/ssrn.3348559

Kanagaretnam, K., Lee, J., Lim, C. Y., \& Lobo, G. J. (2018). Cross-Country Evidence on the Role of Independent Media in Constraining Corporate Tax Aggressiveness. Journal of Business Ethics, 150(3), 879-902. https://doi.org/10.1007/s10551-016-3168-9

Khatami, B. A., Masri, I., \& Suprayitno, B. (2021). PENGARUH NET PROFIT MARGIN, CURRENT RATIO, DAN CAPITAL INTENSITY RATIO TERHADAP TAX AVOIDANCE. Jurnal Ilmiah Akuransi Pancasila, 1 (1).

Kim, J. H., \& Im, C. C. (2017). The Study On The Effect And Determinants Of Small - And Medium-Sized Entities Conducting Tax Avoidance. Journal of Applied Business Research (JABR), 33(2), 375-390. https://doi.org/10.19030/jabr.v33i2.9911

Kovermann, J. H. (2018). Tax avoidance, tax risk and the cost of debt in a bank-dominated economy. Managerial Auditing Journal, 33(8/9), 683-699. https://doi.org/DOI 10.1108/MAJ-12-2017-1734

KPMG, 2017. M\&A Matters - Hybrid and other mismatch rules - experience to date

Lavermicocca, C., \& Buchan, J. (2015). Role of reputational risk in tax decision making by large companies. EJournal of Tax Research, 13, 5-50.

Lin, X., Liu, M., So, S., \& Yuen, D. (2019). Corporate social responsibility, firm performance and tax risk. Managerial Auditing Journal, 34(9), 1101-1130. https:// doi.org/10.1108/MAJ-04-2018-1868

Masri, I., Syakhroza, A., Wardhani, R., \& Samingun. (2019). The role of tax risk management in international tax avoidance practices: Evidence from Indonesia and Malaysia. International Journal of Trade and Global Markets, 12(3/4), 311-322. https:// doi.org/10.15014/IJTGM.2019.101561

Moghadam, A., \& Rahimi, M. (2016). The Study of the Relationship of Conditional 
Conservatism for the Market-to-Book Ratio and Tobin's Q. Open Journal of Accounting, 05(03), 19-24. https://doi.org/10.4236/ojacct.2016.53003

Mulatsih, S., Dharmayanti, N., \& Ratnasari, A. (2019). The Effect of Tax Planning, Asset of Deferred Tax, Deferred Tax Expense on Profit Management (Case Study of Manufacturing Companies Listed on the Stock Exchange 2013-2017 Period). KnE Social Sciences, 3, 933. https:/ / doi.org/10.18502/kss.v3i13.4258

Muryani, \& Chiputyani, L. (2019). The Analysis of Manufacturing Sector in Indonesia. KnE Social Sciences, 3(13), 1200. https:/ / doi.org/10.18502/kss.v3i13.4277

Neuman, S. S., Omer, T. C., \& Schmidt, A. P. (2013). Risk and Return: Does Tax Risk Reduce Firms' Effective Tax Rates? SSRN Electronic Journal. https:// doi.org/10.2139/ssrn.2215129

Neuman, S. S., Omer, T. C., \& Schmidt, A. (2014). Examining the Association between Tax Risk and Tax Outcomes (SSRN Scholarly Paper ID 2215129). Social Science Research Network. https:// doi.org/10.2139/ssrn.2215129

Neuman, S. S., Omer, T. C., \& Schmidt, A. P. (2020). Assessing Tax Risk: Practitioner Perspectives. Contemporary Accounting Research, 37(3), 1788-1827. https:// doi.org/10.1111/1911-3846.12556

Nurfauzi, R., \& Firmansyah, A. (2018). MANAGERIAL ABILITY, MANAGEMENT COMPENSATION, BANKRUPTCY RISK, TAX AGGRESSIVENESS. Media Riset $\begin{array}{lllll}\text { Akuntansi, } & \text { Auditing } & \mathcal{E} & \text { Informasi, } & 18(1),\end{array}$ https:// doi.org/10.25105/mraai.v18i1.2775

Oktaviyani, R., \& Munandar, A. (2017). Effect of Solvency, Sales Growth, and Institutional Ownership on Tax Avoidance with Profitability as Moderating Variables in Indonesian Property and Real Estate Companies. Binus Business Review, 8(3), 183. https:// doi.org/10.21512/bbr.v8i3.3622

Putra, P. D., Syah, D. H., \& Sriwedari, T. (2018). Tax Avoidance: Evidence of As a Proof of Agency Theory and Tax Planning. International Journal of Research E Review, 5(9)

Sankar, B. P. B., \& Leepsa, N. M. (2018). Payment Methods in Mergers and Acquisitions: A Theoretical Framework. International Journal of Accounting and Financial Reporting, 8(1), 170. https:// doi.org/10.5296/ijafr.v8i1.12354

Sari, Y. Y. (2017). 3 The Influence of Company Size, Fixed Asset Intensity, Leverage, Profitability, and Political Connection To Tax Avoidance. 14.

Satyadini, A. E., Erlangga, R. R., \& Vdkg, B. S. (2019). WHO AVOIDS TAXES? AN EMPIRICAL EVIDENCE FROM THE CASE OF INDONESIA. 26.

Skousen, C., Sun, L., \& Wu, K. (2019). The Role of Managerial Ability in Classification Shifting Using Discontinued Operations. In L. L. Burney \& M. A. Malina (Eds.), Advances in Management Accounting (Vol. 31, pp. 113-131). Emerald Publishing Limited. https://doi.org/10.1108/S1474-787120190000031006

Sreesing, P. (2018). Taxes and risk-taking behavior: evidence from mergers and acquisitions in the G7 nations. The Journal of Risk Finance, 19(3), 277-294. https:// doi.org/DOI 10.1108/JRF-12-2016-0170 
Sugeng, S., Prasetyo, E., \& Zaman, B. (2020). Does capital intensity, inventory intensity, firm size, firm risk, and political connections affect tax aggressiveness? JEMA: Jurnal Ilmiah Bidang Akuntansi Dan Manajemen, 17(1), 78. https:// doi.org/10.31106/jema.v17i1.3609

Tang, T. Y. H. (2016). Privatization, tunneling, and tax avoidance in Chinese SOEs. Asian Review of Accounting, 24(3), 274-294. https:/ / doi.org/10.1108/ ARA-08-2014-0091

Wang, F., Xu, S., Sun, J., \& Cullinan, C. P. (2020). Corporate Tax Avoidance: A Literature Review and Research Agenda (SSRN Scholarly Paper ID 3684606). Social Science Research Network. https:/ / doi.org/10.1111/joes.12347

Wang, L. (2015). Tax enforcement, corporate tax aggressiveness, and cash holdings. China Finance Review International, 5(4), 339-370. https://doi.org/10.1108/cfri-12-20140099

Zeng, T. (2019). Relationship between corporate social responsibility and tax avoidance: international evidence. Social Responsibility Journal, 15(2), 244-257. https:// doi.org/10.1108/SRJ-03-2018-0056 